\title{
Alat Gerak hewan dan Manusia Dikemas dalam Media Pop-Up Book
}

\author{
Ni Nyoman Diana Rahayu1*, I Gede Margunayasa² Fina Fakhriyah ${ }^{3}$
}

${ }_{12}$ Program Studi Pendidikan Guru Sekolah Dasar, FIP, Undiksha, Indonesia

${ }^{3}$ Program Studi Pendidikan Guru Sekolah Dasar, Universitas Muria Kudus, Indonesia

\section{ARTICLEINFO}

Article history:

Received 18 March 2020

Received in revised form 30 April 2020

Accepted 5 May 2020

Available online 15 May

2020

\section{kata kunci:}

pop-up book, alat gerak

ADDIE

Keywords:

Pop-up book, motion

equipment, ADDIE

\begin{abstract}
A B S T R A K
Penelitian ini didasari karena buku pedoman yang digunakan guru dan siswa dalam proses pembelajaran masih terbatas terutama pada materi IPA, tampilan buku juga kurang menarik, sehingga menyulitkan guru dalam menjelaskan materi, dan siswa menjadi kurang memahami mengenai materi yang dijelaskan, sehingga menyebabkan pemahaman siswa menjadi menurun, selain itu juga kurangnya penggunaan dan pengembangan media juga mendasari dalam penelitian in. Penelitian ini bertujuan untuk mengembangkan media popup book pada topik alat gerak hewan dan manusia. Penelitian ini merupakan penelitian pengembangan yang menggunakan model pengembangan ADDIE yang terdiri tahapan (1) analisis, (2) perancangan, (3) Pengembangan, (4) implementasi, dan (5) evaluasi.Akan tetapi dalam penelitian ini hanya terbatas pada tahapan pengembangan saja, tahapan implementasi dan evaluasi tidak dilaksanakan karena keterbatasan waktu, sumber daya, dan finansial. Subjek dalam penelitian ini adalah media pop-up book pada topik alat gerak hewan dan manusia, sedangkan objek penelitian ini adalah validitas media pop-up book
\end{abstract} pada topik alat gerak hewan dan manusia. Metode yang digunakan dalam penilaian media pop-up book adalah metode kuesioner. Uji validitas media pop-up book menghasilkan data berupa angka yang dihitung rata-rata skornya kemudian dikonversikan ke dalam tabel pedoman skala lima. Nilai rata-rata validitas media pop-up book yang diperoleh adalah 4.87 dengan kualifikasi sangat baik. Berdasarkan analisis tersebut maka dapat disimpulkan bahwa pengembangan media pop-up book pada topik alat gerak hewan dan manusia dinyatakan valid. Sehingga dengan adanya media ini akan membatu guru untuk menjelakan materi tentang alat gerak hewan dan manusia.

\begin{abstract}
A B S T R A C T
This research is based because the book used by teachers and students in the learning process is still limited, especially in the science material and the display of the book is also less attractive, making it difficult for teachers to explain the material and students become less understanding about the material described, causing student understanding to decrease, in addition, the lack of media use and development also underlies this research. This research aims to develop pop-up book media on the topic of animal and human motion equipment. This research is a development research that uses ADDIE development model which consists of stages (1) analysis, (2) design, (3) Development, (4) implementation, and (5) evaluation. However, this research is only limited to the development stage. , the stages of implementation and evaluation were not carried out due to time, resources and financial limitations. The subject in this research is the pop-up book media on the topic of animal and human motion equipment, while the object of this study is the validity of the pop-up book media on the topic of animal and human motion equipment. The method used in the assessment of pop-up book media is a questionnaire method by providing an assessment sheet to two teachers and two lecturers who are experts in their fields. In the validity test activities of the pop-up book media produces data in the form of numbers which are calculated on average scores then converted into a five-scale guideline table. The average value of the validity of the pop-up book media obtained was 4.87 with very good qualifications. Based on this analysis it can be concluded that the development of the pop-up book media on the topic of animal and human motion equipment declared valid.
\end{abstract}

1 Corresponding author.

Copyright (c) Universitas Pendidikan Ganesha. All rights reserved.

E-mail addresses: dianarahayu5522@gmail.com ${ }^{1}$ (Diana), pakgun pgsd@yahoo.com² ${ }^{2}$ Marguna), fina.fakhriyah@umk.ac.id ${ }^{3}$ (FIna) 


\section{Pendahuluan}

Pembelajaran merupakan usaha sadar dan terencana yang dilakukan oleh pendidik untuk mengkondisikan atau merangsang seseorang agar dapat belajar dengan baik sehingga terjadi perubahan sikap dan tingkah laku siswa dalam jangka waktu yang panjang, serta tercapinya tujuan pembelajaran yang diharapkan (Pane \& Dasopang, 2017). Dalam proses pembelajaran, guru harus mampu menciptakan pembelajaran yang berkualitas, kreatif, dan antusias bagi peserta didik, hal ini tentunya ditentukan oleh cara guru mengajar dan melaksanakan tugas dan fungsinya dengan baik. Salah satu tugas dan fungsi guru dalam proses pembelajaran adalah sebagai fasilitator dan mediator. Guru sebagai fasilitator bertugas memfasilitasi siswa dengan menyediakan fasilitas dalam proses pembelajaran. Sebagai mediator guru hendaknya memiliki pengetahuan dan pemahaman yang cukup tentang media sebagai alat komunikasi untuk mengefektifkan proses pembelajaran. Selain itu guru juga harus memiliki keterampilan memilih dan menggunakan media yang baik dalam proses pembelajaran (Darmadi, 2015).

Media dikatakan sebagai wadah dari pesan yang ingin disampaikan oleh sumber pesan kepada penerima pesan atau sasaran yang akan dituju (Maimunah, 2016). Sejalan dengan hal tersebut media dipandang sebagai alat yang digunakan untuk menyalurkan pesan dari pengirim pesan ke penerima melalui proses komunikasi agar pesan dapat diterima dengan baik dan jelas oleh penerima pesan (Atapukang, 2016).Penggunaan media dalam proses pembelajaran mempunyai fungsi yang sangat penting, yaitu untuk menarik perhatian dan minat siswa belajar, memudahkan guru dalam menyampaikan informasi atau materi pembelajaran, serta membantu siswa untuk memahami materi yang dipelajari, sehingga mampu menciptakan suasana pembelajaran yang menyenangkan dan bermakna (Dewanti, dkk., 2018).

Namun dewasa ini, penggunaan dan pengembangan media dalam pembelajaran belum dilakukan secara optimal, guru hanya menggunakan buku dalam proses pembelajaran, padahal buku yang digunakan masih memiliki banyak kekurangan dan penyajian materi juga kurang menarik (Oktaviarini, 2017). Berdasarkan studi dokumen yang dilakukan pada buku siswa kelas V tema 1 menunjukkan bahwa materi dalam buku siswa, khususnya muatan IPA masih sangat terbatas. Hal tersebut didukung oleh hasil kuesioner yang disebarkan kepada guru dan siswa pada tanggal 7 dan 14 November 2019 di kelas V SD Gugus VII Kecamatan Sukasada tahun pelajaran 2019/2020, diperoleh hasil bahwa (1) 90\% guru menyatakan bahwa materi muatan IPA yang ada pada buku siswa sempit, (2) 50\% guru menyatakan bahwa materi muatan IPA yang terdapat pada buku siswa kurang dalam, dan (3) 83.3\% guru menyatakan bahwa materi IPA yang terdapat dalam buku siswa sangat perlu untuk dikembangkan. Selain itu, hasil kuesioner yang telah disebarkan kepada siswa juga diperoleh data bahwa, 90\% siswa menyatakan materi muatan IPA pada buku siswa kurang lengkap dan $77 \%$ siswa menyatakan materi muatan IPA yang terdapat di buku siswa perlu dikembangkan. Hal ini dikarenakan siswa masih mencari sumber atau jawaban-jawaban di internet saat mengerjakan tugas dan beberapa materi yang terdapat pada buku siswa masih terbatas dan belum lengkap.

Keterbatasan materi muatan IPA yang terdapat dalam buku siswa mengakibatkan pemahaman sains siswa menjadi menurun, hal ini didukung oleh hasil PISA tahun 2018 yang dikeluarkan oleh OECD kemampuan sains siswa Indonesia memperoleh skor 389 yang berada di bawah rata-rata skor OECD yakni 489. Jika hal ini terus dibiarkan maka kualitas pendidikan di Indonesia akan terus menurun (Indriani, 2019).Keterbatasan materi atau bahan ajar dan guru yang hanya memanfaatkan buku dalam proses pembelajaran juga menyebabkan guru menjadi kesulitan dalam menjelaskan materi, sehingga membuat siswa mudah merasa bosan, mudah melupakan materi atau konsep yang diajarkan, serta menyebabkab pembelajaran menjadi tidak bermakna dan pemahaman siswa menjadi terbatas (Mustofa \& Syafi'ah, 2018). Berdasarkan hal tersebut, maka perlu adanya perubahan dan inovasi dalam sistem pembelajaran sehingga pembelajaran lebih menyenangkan, bermakna, serta mendorong peningkatan kemampuan siswa. Salah satu cara yang dilakukan dengan mengembangkan media dalam proses pembelajaran. Salah satu jenis media pembelajaran yang bisa dikembangkan adalah media pop-up book.

Pop-up book adalah sebuah buku yang ketika dibuka dapat menampilkan bentuk tiga dimensi dan gerak yang dapat dikreasikan melalui penggunaan kertas sebagai bahan lipatan, gulungan, bentuk, ataupun roda (Oktaviarini, 2017). Media pop-up book mempunyai keunggulan daripada media lainnya, adapun keunggulan media ini adalah (1) dapat memvisualisasikan gambar menjadi lebih menarik, (2) pop-up book dapat digunakan sebagai bahan ajar yang membantu siswa secara individu maupun secara

Copyright (C) Universitas Pendidikan Ganesha. All rights reserved.

1 Corresponding author.

E-mail addresses: dianarahayu5522@gmail.com ${ }^{1}$ (Diana), pakgun pgsd@yahoo.com² (Marguna), fina.fakhriyah@umk.ac.id ${ }^{3}\left(\right.$ FIna $\left.^{2}\right)$ 
berkelompok belajar mandiri, (3) pop-up book bersifat praktis, dapat menambah semangat serta minat siswa dalam belajar, serta dapat mempermudah guru dalam menjelaskan materi dan meningkatkan hasil belajar siswa, (4) tampilan pop-up book yang unik dan menarik menjadi salah satu keunggulan, pop-up book daripada media pembelajaran lainnya, (5) pop-up book ini memiliki dimensi gambar yang dapat timbul ketika halaman dibuka (Masturah, dkk., 2018).

Dalam mengembangkan media pop-up book terdapat kriteria dan teknik yang meliputi (1) popup book dapat dibuka dan ditutup tanpa merusak atau merobek lembaran kertas yang lain, (2) kertas lembaran pop-up book tidak berpotongan sehingga tidak ada halangan saat membuka atau menutup buku, (3) pop-up book rapi saat tertutup, (4) pop-up book memiliki unsur bentuk, warna, dan tekstur yang menarik, dan (5) pop-up book tidak mudah rusak (Fadillah \& Lestari, 2016). Hal tersebut didukung oleh penelitian tentang media pop-up book yang dilakukan oleh Masturah, dkk., (2018) yang menyatakan bahwa hasil uji ahli dan uji coba memperoleh skor 95,8\% dari ahli desain pembelajaran memperoleh skor $88 \%$ dan ahli media pembelajaran memperoleh hasil 98,5\%. Pada uji coba perorangan memperoleh skor 92\%, uji coba kelompok kecil memperoleh skor $91,66 \%$ dan uji coba lapangan memperoleh skor 90,8\%. Berdasarkan hasil yang diperoleh media pop-up book dinyatakan valid.

Penelitian ini juga merujuk pada hasil kuesioner yang dilakukan kepada guru dan siswa kelas $\mathrm{V}$ Gugus VII Kecamatan Sukasada tahun pelajaran 2019/2020, memperoleh hasil bahwa 77\% siswa menyatakan media pop-up book sangat perlu dikembangkan dan 100\% guru menyatakan sangat setuju jika materi dikembangkan dalam bentuk media pop-up book untuk membantu dalam proses pembelajaran. Disampng itu, berdasarkan hasil wawancara yang telah dilaksanakan pada tanggal 7 dan 14 November 2019 di Gugus VII Kecamatan Sukasada salah satu topik pada muatan IPA yang dikatakan terbatas adalah topik alat gerak pada hewan dan manusia. Hal ini juga didukung oleh studi dokumen yang telah dilakukan pada buku tematik siswa kelas $V$ yang menunjukkan bahwa topik alat gerak hewan dan manusia, khususnya pada alat gerak manusia belum dijelaskan tentang persendian pada manusia. Apabila topik tersebut dikembangkan dalam sebuah media pop-up book tentunya dapat membantu guru dalam menyampaikan materi topik alat gerak hewan dan siswa akan mendapatkan pengalaman belajar secara langsung sesuai karakteristik anak usia sekolah dasar. Adapun tujuan penelitian ini adalah untuk mengembangkan media pop-up book pada topik alat gerak hewan dan manusia kelas V sekolah dasar tahun pelajaran 2019/2020 yang sudah teruji validitasnya.

\section{Metode}

Penelitian ini merupakan penelitian pengembangan media pop-up book. Model pengembangan yang digunakan adalah model ADDIE. Model ADDIE merupakan salah satu model yang disusun secara sistematis dan berpijak pada landasan teoritis desain pembelajaran dalam upaya pemecahan masalah belajar yang sesuai dengan karakteristik siswa. Model ADDIE terdiri atas lima tahapan yaitu, (1) analisis (analyze), (2) perancangan (design), (3) pengembangan (development), (4) implementasi (implementation) dan (5) evaluasi (evaluation) (Tegeh \& Jampel, 2017). Akan tetapi tahapan dalam penelitian ini hanya dilaksanakan sampai tahap pengembangan (development) dikarenakan keterbatasan waktu, sumber daya, dan finansial.

Secara terinci tahap pengembangan media ii sebagai berikut; 1) Tahapan yang dilakukan adalah, tahap analisis (analyze), tahap ini dilakukan atas empat kegiatan yaitu (1) analisis kebutuhan dilakukan untuk mengetahui hal-hal yang diperlukan guru dan siswa dalam proses pembelajaran khusunya pada topik alat gerak hewan dan manusia, (2) analisis karakteristik bertujuan untuk mengetahui karakteristik siswa yang akan menggunakan media yang dikembangkan, (3) analisis kurikulum dilakukan dengan menganalisis $\mathrm{KI}$, KD, indikator pencapaian kompetensi, tujuan pembelajaran, dan materi pembelajaran sebagai acuan dalam menyusun media yang dikembangkan, (4) analisis media dilakukan untuk mengetahui kriteria media yang baik; 2) Tahapan perancangan (design), pada tahap ini dilakukan perancangan media pop-up book pada topik alat gerak hewan dan manusia di kelas $\mathrm{V}$ sekolah dasar. Langkah awal yang dilakukan adalah menentukan topik yang akan dikembangkan. Setelah itu dilanjutkan dengan melakukan bimbingan kepada dosen mengenai media yang pop-up book yang dikembangkan untuk mendapatkan masukan atau saran sehingga dapat melakukan revisi pada bagian media yang dikembangkan; 3) Tahap pengembangan (development) dilaksanakan dengan mengembangkan media pop-up book pada topik alat gerak hewan dan manusia, yang telah dikonsultasikan kepada dosen pembimbing. Selanjutnya diperbaiki sesuai saran yang diberikan.Setelah media pop-up book selesai dikembangkan, tahap selanjutnya adalah melakukan uji validitas media pop-up book yang dikembangkan. Uji validitas media pop-up book dilaksanakan melalui tahap review yang dilakukan oleh dua dosen dan dua guru yang ahli dalam bidangnya. 
Subjek dalam penelitian ini adalah media pop-up book pada topik alat gerak hewan dan manusia, sedangkan objek penelitian ini adalah validitas media pop-up book pada topik alat gerak hewan dan manusia. Jenis data yang diperoleh dalam penelitian ini adalah data kuantitatif dan kualitatif. Data kualitatif adalah data yang disajikan dalam bentuk kata-kata yang diperoleh dari review uji ahli berupa masukan, saran, tanggapan dan kritik (Agung, 2014). Data kuantitatif dalah data yang berupa skor atau nilai yang diperoleh dari review uji ahli. Metode pengumpulan data dalam penelitian pengembangan ini menggunakan metode kuesioner. Instrumen yang digunakan dalam penelitian ini berupa rating scale.Untuk menguji validitas isi instrumen dilakukan penilaian pakar (judges) yang ahli dalam bidangnya. Uji validitas isi dilaksanakan menggunakan rumus Gregory. Metode dan teknik analisis data yang digunakan dalam penelitian pengembangan ini adalah teknik analisis statistik deskriptif kualitatif dan statistik deskriptif kuantitatif. Metode analisis statistik deskriptif kualitatif digunakan untuk mengolah hasil review atau data, masukan, saran, dan kritik yang diberikan oleh ahli (dosen, dan guru) terhadap media yang dikembangkan melalui pemberian kuesioner, sedangkan metode analisis statistik deskriptif kuantitatif digunakan untuk mengolah data atau skor yang diberikan oleh guru dan dosen sebagai ahli. Skor yang diperoleh, kemudian dihitung rata-ratanya dengan menggunakan rumus mean. Selanjutnya, skor rata-rata validitas media dikonversi ke dalam tabel pedoman skala lima. Media popup book dinyatakan valid apabila hasil rata-rata media pop-up book minimal berada pada kualifikasi baik dengan rentang $3.01<\mathrm{x} \leq 4.01$.

\section{Hasil dan Pembahasan}

Berdasarkan hasil analisis data media pop-up book menggunakan rumus mean, maka diperoleh hasil sebagai berikut. Hasil analisis data media pop-up book, didapatkan skor rata-rata sebesar 4.87dengan kualifikasi sangat baik. Skor rata-rata media pop-up book jika dikonversikan ke dalam tabel pedoman skala lima, berada pada kualifikasi sangat baik. Untuk lebih jelasnya, hasil validasi media dapat dilihat pada Gambar 01.

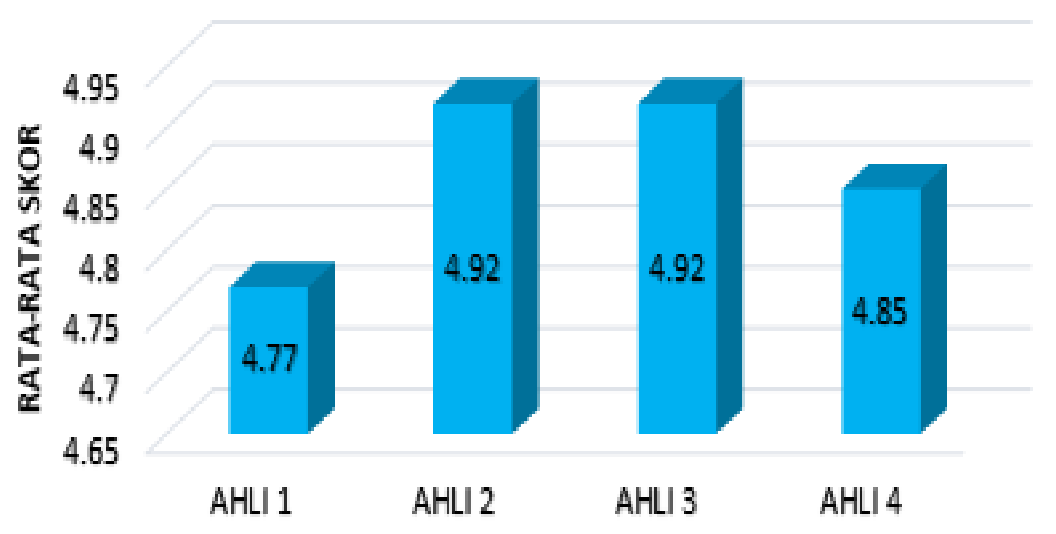

Gambar 01

Diagram Hasil Validasi Media

Penelitian ini merupakan penelitian untuk mengembangankan media pop-up book pada topik alat gerak hewan dan manusia. Pengembangan media pop-up book sangatlah penting untuk menjawab permasalahan yang ada di sekolah dalam hal proses pembelajaran, karena media pop-book mengandung unsur warna, gambar, dan gerak yang menarik, serta dapat meningkatkan daya imajinasi siswa terhadap materi yang disampaikan (Fitriani \& Fajriah, 2017). Gambar media pop-up book yang dikembangkan dapat dilihat pada Gambar 02. Gambar ini bertujuan untuk memberikan ilustrasi media pop-up book yang dikembangkan. 


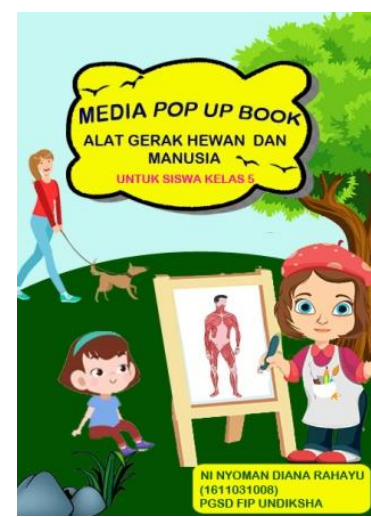

(a) Cover Depan Media Pop-Up Book

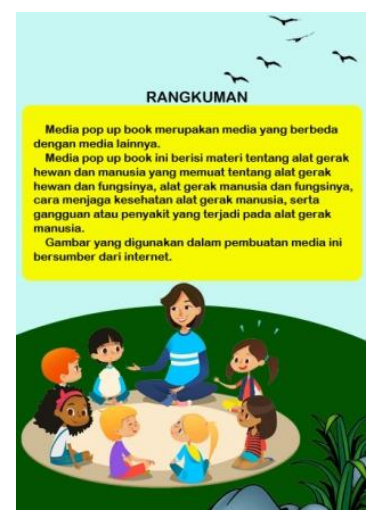

(b) Cover Belakang Media Pop-Up Book
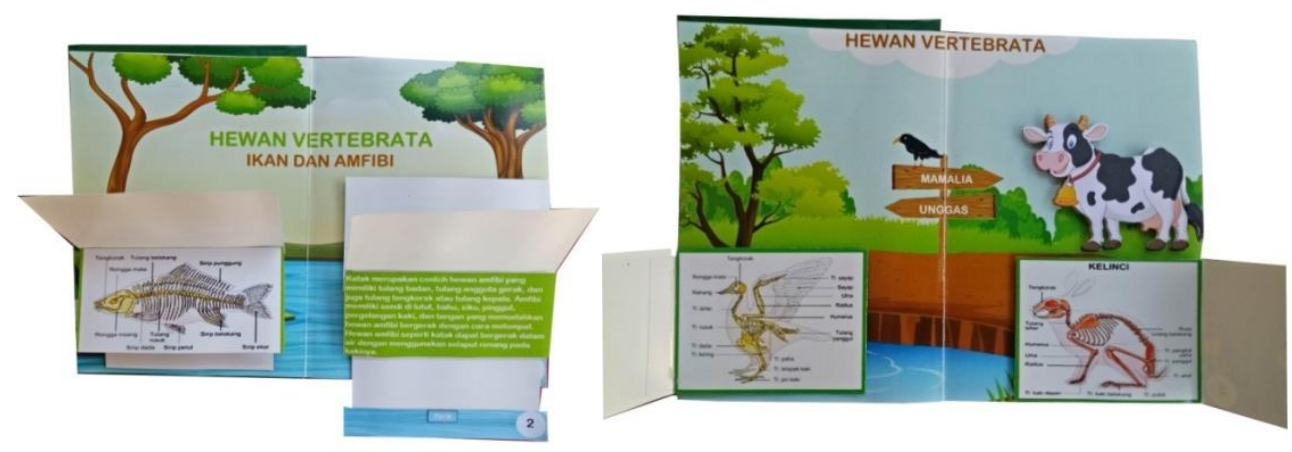

(c) Isi Media Pop-Up Book

Gambar 02

Media Pop-Up Book

Berdasarkan deskripsi yang diuraikan sebelumnya, penelitian pengembangan ini menggunakan model ADDIE yang terdiri dari tahapan (1) analisis (analyze), (2) perancangan (design), (3) pengembangan (development), (4) implementasi (implementation) dan (5) evaluasi (evaluation).

Pada tahap analisis (analyze) dilakukan beberapa tahapan yaitu, analisis kebutuhan, analisis karakteristik siswa, analisis kurikulum, dan analisis media. Analisis kebutuhan dilakukan dengan memberikan kuesioner dan melakukan wawancara kepada guru dan siswa diperoleh hasil bahwa $90 \%$ guru menyatakan materi muatan IPA yang ada pada buku siswa sempit, 50\% guru menyatakan materi muatan IPA pada buku siswa kurang dalam, 83.3\%, dan 90\% siswa menyatakan materi muatan IPA pada buku siswa kurang lengkap, analisis kurikulum dilakukan dengan menentukan kompetensi inti, kompetensi dasar, tujuan pembelajaran dan materi atau topik yang dijadikan acuan dalam pembuatan media, analisis karakteristik siswa sekolah dasar diperoleh hasil bahwa siswa sangat senang belajar menggunakan benda-benda konkret atau gambar-gambar yang memiliki warna menarik untuk memahami materi yang dijelaskan. Hal tersebut sesuai dengan teori perkembangan piaget yang menyatakan usia anak sekolah dasar berada pada kisaran umur 6-12 dan berada pada tahap operasional konkret (Ibda, 2015). Sehingga berdasarkan hal tersebut perlu dikembangkannya materi yang terdapat dalam buku siswa dalam bentuk media pop-up book untuk menarik minat belajar siswa, analisis media dilakukan untuk mengetahui karakteristik media yang baik.

Setelah dilakukan tahap analisis, kemudian dilanjutkan dengan tahap perancangan (design) media pop-up book, pada tahap ini yang dilakukan adalah pemilihan software serta pemilihan alat dan bahan yang digunakan dalam pembuatan media. Software yang digunakan dalam mendesain media ini adalah Photoshop CS5, media yang dikembangkan berukuran 14,8 cm x $21 \mathrm{~cm}$, dengan jumlah 13 halaman. Alat dan bahan dalam pengembangan media ini adalah gunting, cutter, double side tape, double side tape foam, kertas art paper, dan kertas glossy.

Tahap selanjutnya adalah tahap pengembangan (development). Pada tahap pengembangan media pop-up book yang dilakukan adalah pengumpulan alat dan bahan yang diperlukan dalam pengembangan media pop-up book, (2) penyusunan materi yang akan dikembangkan dalam media pop-up book, (3) pencetakan lembar halaman pop-up book, (4) perancangan media pop-up book dengan menggunakan teknik tertentu, (5) penyatuan bagian isi pop -up book dengan cover. Setelah media 
selesai dikembangkan selanjutnya dilakukan uji validitas media melalui tahap review yang dilakukan oleh ahli yaitu dua orang dosen dan dua orang guru dengan memberikan kuesioner validitas media. Setelah dilakukan penilaian, diperoleh komentar dan saran dari ahli terhadap media yang dikembangkan. Berdasarkan analisis validitas media pop-up book yang telah dilaksanakan diperoleh rata-rata skor validasi 4.87 , berdasarkan pedoman konversi skala lima memperoleh kualifikasi sangat baik.

Berdasarkan hasil kualifikasi yang dilakukan menunjukkan bahwa media pop-up book yang dikembangkan sangat layak digunakan untuk membantu guru dan siswa dalam proses pembelajaran. Hal tersebut sesuai dengan peranan media sebagai alat yang membantu guru untuk memperjelas materi pembelajaran, dalam hal ini media digunakan guru sebagai penjelasan verbal mengenai materi yang dibahas, selain itu media juga berperan sebagai sumber belajar bagi siswa, yang artinya media tersebut berisikan materi yang harus dipelajari siswa baik secara individu ataupun kelompok, dengan adanya media membatu tugas guru dalam proses pembelajaran (Mustika, 2015).

Pemilihan media pop-up book dalam proses pembelajaran sangatlah tepat. Selain sesuai dengan karakteristik siswa, media ini juga dipandang menarik dan praktis digunakan. Dengan tampilan media yang menyerupai tiga dimensi dipandang dapat menambah semangat belajar siswa (Sholeh, 2019). Sejalan dengan hal tersebut media visual yang berbentuk tiga dimensi juga akan lebih efektif dan memudahkan siswa memahami materi pembelajaran sehingga siswa menjadi lebih semangat dan tidak mudah bosan dalam proses pembelajaran. Dengan menggunakan media yang bervariasi dan menarik membuat pembelajaran tidak monoton (Sari \& Kasiyati, 2018). Penggunaan media pop-up book dalam proses pembelajaran juga membuat siswa lebih fokus dalam mengamati setiap materi yang terdapat dalam media (Wati \& Ulhaq Zuhdi, 2017). Adapun keunggulan media popup book dibandingkan dengan media lainnya adalah pop-up bookdibuat dengan menggunakan kertas tebal sehingga tidak mudah rusak atau robek; pada setiap halaman pop-up book berisi gambar menarik yang ketika dibuka terdapat gambar menarik dan timbul (tiga dimensi); pop-up book dapat digunakan dalam proses pembelajaran baik digunakan secara mandiri atau berkelompok (Anggraini, dkk., 2019).

Berdasarkan hasil penelitian yang dilakukan oleh Dewanti, dkk (2018), menyatakan bahwa hasil validasi media, diperoleh presentase $97.79 \%$ dari validasi ahli media, 94.93\% dari ahli materi, 95.17\% dari ahli pengguna (guru), dan 95\% dari uji coba pengguna (siswa). Hasil validasi secara keseluruhan yaitu 95.72\% dengan kriteria "Sangat Valid", sehingga media ini sangat layak untuk digunakan dalam pembelajaran Tematik pada sutema Lingkungan Tempat Tinggalku. Penelitian lain yang dilakukan oleh Mustofa \& Syafi'ah (2018), menyatakan bahwa media pop-up book yang dikembangkan dinyatakan layak digunakan dengan perolehan rata-rata skor 4,44 dari ahli materi, rata-rata skor 4.80 dari ahli media, dan rata-rata skor 4.72 dari ahli pengguna, keseluruhan hasil perolehan rata-rata skor masuk dalam kategori sangat baik. Sedangkan respon siswa terhadap media pop-up book pada uji coba terbatas mendapatkan rata-rata 95\% dengan kategori sangat baik Berdasarkan hasil analisis data diperoleh kesimpulan bahwa media pop up book materi pokok kenampakan permukaan bumi pada mata pelajaran IPA kelas III SD yang telah dikembangkan layak untuk digunakan. Berdasarkan penelitian yang telah dilakukan, diyakini bahwa media pop-up book pada topik alat gerak hewan dan manusia diimplementasikan dapat membantu guru dalam menjelaskan materi, membantu siswa memahami materi, serta dapat menarik minat siswa belajar.

\section{Simpulan}

Berdasarkan hasil penelitian dan pembahasan dapat disimpulkan bahwa pengembangan media pop-up book pada topik alat gerak hewan dan manusia di kelas V SD Gugus VII Kecamatan Sukasada tahun pelajaran 2019/2020 dengan rata-rata nilai validitas media pop-up book yang dikonversikan ke dalam tabel pedoman skala lima memperoleh skor 4.87 dengan kualifikasi sangat baik, sehingga media pop-up book layak dikembangkan dan digunakan dalam proses pembelajaran.

Berdasarkan hasil penelitian yang telah dilakukan, beberapa saran yang bisa disampaikan dalam penelitian pengembangan ini, pertama media pop-up book yang dikembangkan dapat dijadikan bahan referensi oleh guru dalam melaksanakan proses pembelajaran terutama pada topik alat gerak hewan dan manusia, serta kedepannya diharapkan guru dapat mengembangkan media sejenis untuk menarik minat belajar siswa dan media pop-up book juga bisa dikembangkan pada topik lainnya. Kedua, bagi kepala sekolah hendaknya memfasilitasi guru dengan mengikutsertakan guru-guru dalam mengikuti pelatihan pengembangan media dalam proses pembelajaran. Ketiga bagi peneliti lain diharapkan penelitian ini dapat dijadikan bahan referensi pada penelitian sejenis, serta peneliti lain juga dapat melanjutkan penelitian ini pada tahap implementasi melalui penelitian eksperimen. 


\section{Daftar Rujukan}

Agung, Anak Agung Gede. 2014. Metodologi Penelitian Pendidikan. Malang: Aditya Media Publishing.

Anggraini, dkk. 2019. "Development of Pop-Up Book Integrated with Quranic Verses Learning Media on Temperature and Changes in Matter". Journal of Physics, (hlm 1-9).

Atapukang, Nurmasa. 2016. "Kreatif Membelajarkan Pembelajaran dengan Menggunakan Media Pembelajaran yang Tepat Sebagai Solusi dalam Berkomunikasi". Jurnal Media Komunikasi Geografi, Volume 17, Nomor 2 (hlm. 45-52).

Darmadi, Hamid. 2015. "Tugas, Peran, Kompetensi, Dan Tanggung Jawab Menjadi Guru Profesional". Jurnal Edukasi, Volume 13, Nomor 2 (hlm. 161-174).

Dewanti, Handaruni., dkk. 2018. "Pengembangan Media Pop-Up Book untuk Pembelajaran Lingkungan Tempat Tinggalku Kelas IV SDN 1 Pakunden Kabupaten Ponorogo". JKTP, Volume 1, Nomor 2 (hlm. 221-228).

Fadillah, Rachmadini Nur \& Ika Lestari 2016. "Buku Pop-Up untuk Pembelajaran Bercerita Siswa Sekolah Dasar". PERSPEKTIF Ilmu Pendidikan, Volume 30, Nomor 1 (hlm. 21-26).

Fitriani, Lutfi \& Khusnul Fajriah. 2017. "Pengembangan Media Pop-Up Book Tema 5 Pahlawanku pada Model Pembelajaran Number Head Together Kelas IV SDN 01 Gintung". Kalam Cendekia, Volume 6, Nomor 3 (hlm. 29-34).

Ibda, Fatimah. 2015. "Perkembangan Kognitif: Teori Jean Piaget". Jurnal Intelektualita, Volume 3, Nomor 1 (hlm. 27-38).

Indriani. 2019. Hasil PISA Tunjukkan Perspektif Pendidikan Indonesia. Antarnews.

Maimunah. 2016. "Metode Penggunaan Media Pembelajaran". Jurnal Al-Afkar, Volume 5, Nomor 1 (hlm. 1-24).

Masturah, Elisa Diah., dkk. 2018. "Pengembangan Media Pembelajaran Pop-Up Book pada Mata Pelajaran IPA Kelas III Sekolah Dasar". Jurnal EDUTECH Universitas Pendidikan Ganesha, Volume 6, Nomor 2 (hlm. 212-221).

Mustika, Rieka. 2015. "Media Pembelajaran Sistem Audio untuk Pemberdayaan Pendidikan di Komunitas Masyarakat". Jurnal Masyarakat Telematika Dan Informasi, Volume 6, Nomor 1 (hlm. 57-68).

Mustofa, Refita \& Rohmatus Syafi'ah. 2018. "Pengembangan Media Pembelajaran Pop Up Book Materi Kenampakan Permukaan Bumi Mata Pelajaran IPA Kelas III SD". ELSE (Elementary School Education Journal), Volume, 2, Nomor 2 (hlm. 30-41).

Oktaviarini, Nourma. 2017. "Pengembangan Media Pembelajaran Pop-Up Book Tema Lingkungan dan Alam Sekitar untuk Siswa Kelas IV SD di Kabupaten Blitar". Jurna Pena SD, Volume 03, Nomor 01 (hlm. 70-87).

Pane, Aprida \& Muhammad Darwis Dasopang. 2017. "Belajar Dan Pembelajaran". FITRAH:Jurnal Kajian Ilmu-Ilmu Keislaman, Volume 3, Nomor 2 (hlm. 333-352).

Sari, Yuvika \& Kasiyati. 2018. "Efektivitas Media Pop-Up Book untuk Meningkatkan Kemampuan Mengenal Bagian-Bagian Tubuh pada Siswa Tunagrahita Ringan". Jurnal Penelitian Pendidikan Kebutuhan Khusus, Volume 6, Nomor 1 (hlm. 106-111).

Sholeh, Muhammad. 2019. "Pengembangan Media Pop-Up Book Berbasis Budaya Lokal Sub Tema Keberagaman Budaya Bangsaku Siswa Kelas IV Sekolah Dasar". Jurnal Gentala Pendidikan Dasar, Volume 4, Nomor 1 (hlm. 1-15).

Tegeh, I Made \& I Nyoman Jampel. 2017. Metode Penelitian Pengembangan. Singaraja: Universitas Pendidikan Ganesha.

Wati, Elis Trisdiana \& Ulhaq Zuhdi. 2017. "Pengaruh Media Pop-Up Book terhadap Hasil Belajar Siswa Tema Ekosistem Kelas V SDN Karangpilang 1 Surabaya". JPGSD, Volume 05, Nomor 03 (hlm. 913-923). 